\title{
Web-Based Village Information System in Dalegan Village - Panceng District - Gresik Regency
}

\author{
Author \\ Correspondence \\ Universitas Muhammadiyah Gresik \\ langgrapradipta13@gmail.com
}

Pandu Setiaji, Langgra Mayrezka Pradipta, Agus Budhi Utomo, Andi Rahmad Rahim

\begin{abstract}
:
The development of information technology has made the internet as a very important requirement to explore various information needed. The benefits of the internet are quite large especially in the world of business, entertainment and education. Dalegan Village is a village that has a lot of natural wealth such as white sand beach tourism, hill prohibit, legen drinks, fish crackers and various other fish preparations, but all these riches have not been fully exposed in cyberspace. This program aims to build a web-based village information system to expose the history and profile of the village and optimize the existence of the natural wealth of the village of Dalegan so that information about the natural wealth can be conveyed to all internet users so that it can increase the interest of tourists who will visit and increase the budget of the village income.
\end{abstract}

Keywords: Dalegan Village, White sand beach, Village Information System, Internet.

\section{Introduction}

Dalegan Village is one of the villages in Panceng Subdistrict located in the northern part of Gresik City. Dalegan Village has pretty much natural beauty such as; White Sand Beach, Larangan Hill, and rice fields that can spoil your eyes. The majority of the people work as fishermen, farmers, collectors of legen drinks, breeders, and UKM.

Efforts to advance the potential of Dalegan Village are very effective if the application of a websitebased information system so that a broad audience can find out a variety of potential, important information, and natural beauty related to Dalegan Village through internet media.

Based on data from the Government Administration of Dalegan Village in 2018, the population of Dalegan Village is 7,792 people with 3,966 men and 3,826 women.

The condition of this village is good and evolve, with village roads that have been improved by using asphalt and neatly arranged paving. Village facilities are also used to the maximum extent such as existing street lighting along the road, there is a mosque which is the center of activity, elementary schools and secondary schools also exist in this village.

The purpose of making "Dalegan Village Web Based Information System" is a program to elevate Dalegan Village in the wider community, especially the potential and various tourism possessed by the village.

The benefit for Dalegan Village with this system is that it can be used to introduce to the general public about the organizational structure, activities, potential, and tourism in Dalegan Village to be more effective and efficient. Products produced by the people of Dalegan Village can be introduced to the wider community so that more consumers buy products produced from Dalegan Village, as well as attract the
Received: 08 Agustus 2019. Accepted: 29 Agustus 2019

interest of the wider community to visit Dalegan Village for holidays.

\section{Method}

Dalegan Village Website Development has 5

stages.

1. Objective - Determine the purpose and purpose of making a website.

2. Design - involves graphic or multimedia design, but must be in accordance with the objectives. In design, layout must also be determined, menu structure, and most importantly material. Material includes the profile you want to display, business, goods / services, and so on. Good web material that benefits visitors will bring good traffic.

3. Making - In general, web creation can be grouped in 2 ways; Create your own web and programs from scratch. This method requires a team that has various expertise such as HTML, CSS, Javascript, graphic design (Photoshop), and web scripting programming (PHP, JSP, ASP).

4. Use a CMS (Content Management System) like WordPress or Joomla. CMS is a ready-made platform that can be "custom" to suit our needs.

5. Using Open SID for the framework. OpenSID is a Village Information System (SID) that is deliberately designed to be open and can be developed jointly by the SID caring community. 


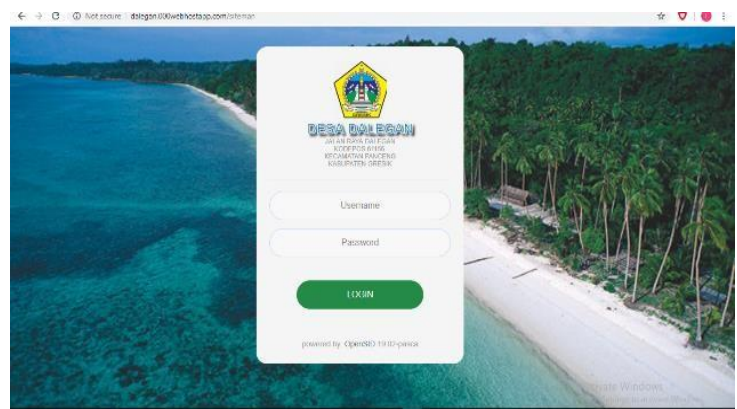

Figure 3.1. Display login page for administrators using OpenSID

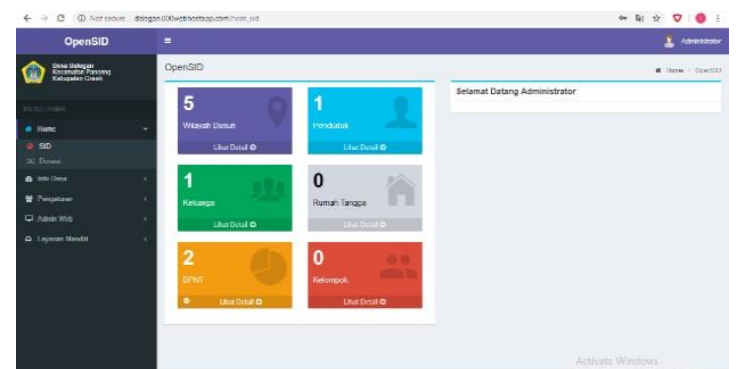

Figure 3.2. Display after logging in as administrator

The next step is to determine what menus will be displayed on the website to convey information that will be submitted online. Next is the page display to set the menu layout on the Dalegan Village website:

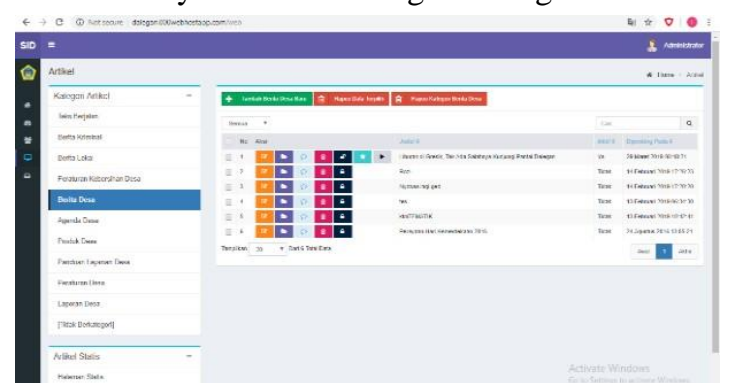

Figure 3.3. Display page to set the layout of the Dalegan Village website menu.

The next step is to add content to the menu. Each content contains information about the village of Dalegan (as per picture 3).

The Dalegan Village website has been completed with the steps above. That way the Dalegan Village website is ready to be socialized to the Dalegan Village apparatus so that the website can be well managed and useful..

\section{Results and Discussion}

The function of the Dalegan Village website is to be an information media for publications of the Dalegan Village with the public so that it generates good reception of information.

The role of Dalegan Village website manager is very necessary. So that the website is always up to date. The types of users provided are Administrator, Editor, and Viewer.

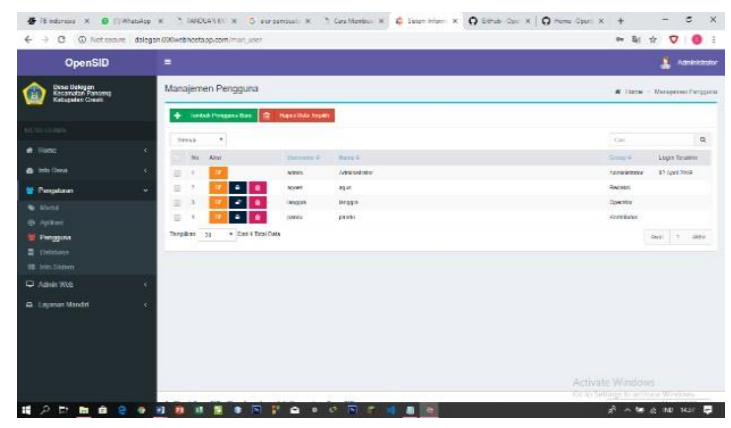

Figure 3.4. Display user addition

Administrators have full access rights to the website. Administrators can do everything about the website it manages. Administrators can add new users, delete users, change the user's role to the website. Administrators have full control over article posts, website pages, and themes applied to the website.

This role as Administrator is basically provided for website owners and gives full control over the website. If you are running a multi-user PHP website, you must be very careful about choosing who will have the role of Administrator.

The editor is the person / team in charge of checking and improving the material displayed on the village website. Usually also plays a role in determining the contents of the village website.

Role of information processing: write, edit all articles and website elements.

Operators have access rights, among others to: Provide services to the public using SID, amend and add the latest articles, Manage comments, Enter article material, Enter material for menus (static and dynamic menus). Manage village data and profiles, Back up village databases and village folders regularly.

A contributor is a person who writes articles for editorial approval to be displayed on the village website. Role of information processing: write, edit articles by yourself.

A visitor page is a page that is accessed by all visitors. On the visitor page contains information about the village of Daleganyaitu village profile, vision and mission, programs, activities and products of the village of Dalegan.

Visitors can also interact by providing feedback or by responding to existing information. Visitors do not need to $\log$ in to view web pages, simply by opening http://dalegan.000webhostapp.com/first.

The following are some views for visitor pages: 


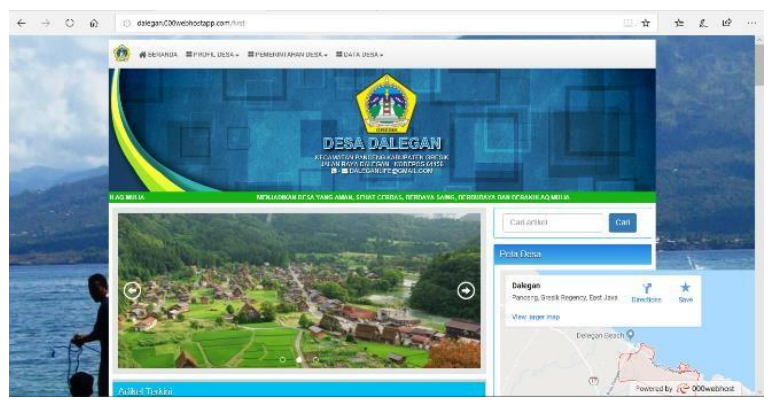

Figure 3.5. Display of the Home page on the Dalegan Village website

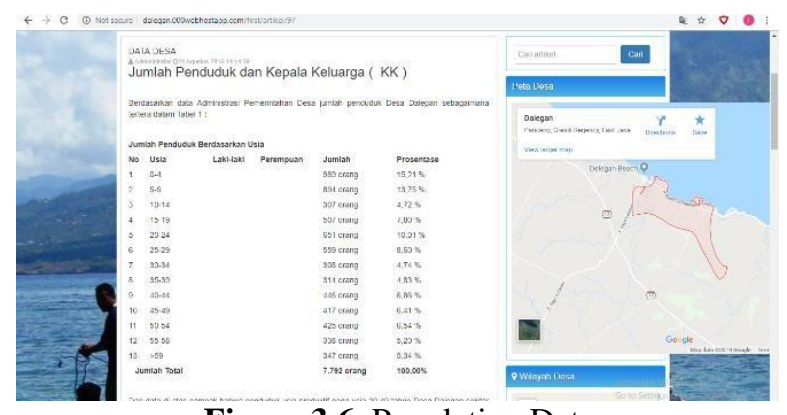

Figure 3.6. Population Data

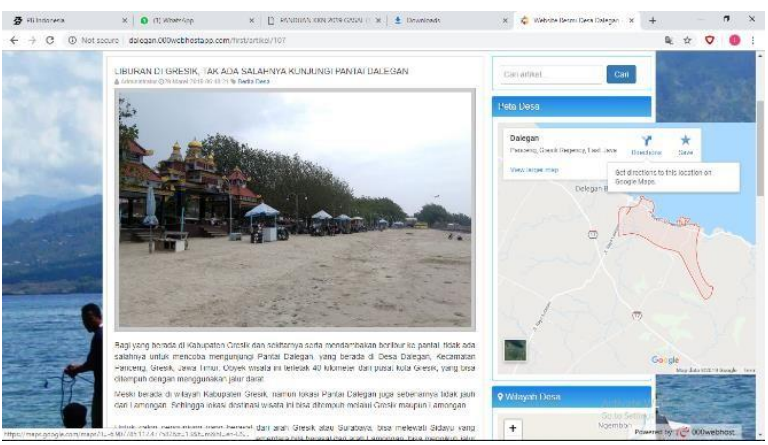

Figure 3.7. Eskpose Travel

\section{Conclusion}

With the Dalegan Village website, it provides convenience to the public in accessing information without limited distance and time. Website with address http://dalegan.000webhostapp.com/first can be a means of publication or delivery of information other than through brochures and invitations.

Dalegan Village website is a means of information and publications that can be accessed quickly by the community both locally and throughout the world community.

The Dalegan Village website should always be updated in terms of information so that visitors can find out the latest information from the Dalegan Village.

It is hoped that the Dalegan Village government will provide special resources to manage the Dalegan Village website, so that the website is always updated with the latest information related to the village or others so that it is always interesting to visit.

\section{Reference}

Alex, Fahrudin, Bambang, Eka Purnama.Pembangunan Sistem Informasi Layanan Haji Berbasis Web
Pada Kelompok Bimbingan Ibadah Haji Ar Rohman Mabrur. Kudus: Indonesian Jurnal on Computer Science - Speed (IJCSS) 13 Vol 9 No 2

- Agustus 2012. ISSN 1979 - 9330.

Anhar. Panduan Menguasai PHP \& MySQL Secara

Otodidak. Media Kita. Jakarta: 2010.

Hambali,Yusuf.(2018).Kategori Pengguna. Dikutip 8 April 2019 dari GitHub,Inc. :https://github.com/OpenSID/opensid/wiki/Penga turan-Pengguna

Medi,Suhartanto. Pembuatan Website Sekolah Menengah Pertama Negeri 3 Delanggu Dengan Menggunakan Php Dan Mysql. Indonesian Jurnal on Computer Science - Speed (IJCSS) 15. FTI UNSA.Vol 10 No 1 .Februari 2012. ijcss.unsa.ac.id, ISSN 1979 - 9330.

Nugroho,Bunafit.Membuat Website Sendiri Deangan PHP-MSQL. Mediakit. 2009. 